GRASAS Y ACEITES 66 (2)

April-June 2015, e072

ISSN-L: 0017-3495

doi: http://dx.doi.org/10.3989/gya.0835142

\title{
Effect of temperature on the oxidation of soybean biodiesel
}

\author{
G.G. Pereira $^{\mathrm{a}, \varpi}$, A. Morales ${ }^{\mathrm{b}}$, S. Marmesat ${ }^{\mathrm{b}}$, M.V. Ruiz-Méndez ${ }^{\mathrm{b}}$, \\ D. Barrera-Arellano and M.C. Dobarganes ${ }^{\mathrm{b}}$ \\ ${ }^{a}$ Fats and Oils Laboratory, Faculty of Food Engineering, University of Campinas - UNICAMP, 13083-970 Campinas, SP, Brazil \\ ${ }^{b}$ Instituto de La Grasa (CSIC), Campus University Pablo de Olavide, 41013 Seville, Spain \\ ${ }^{\square}$ Corresponding author: pereiragg@ymail.com
}

Submitted: 26 August 2014; Accepted: 04 December 2014

SUMMARY: This paper proposes to examine the effect of temperature on the oxidation behavior of biodiesel. Soybean biodiesel was oxidized at different temperatures (room temperature, 60 , and $110^{\circ} \mathrm{C}$ ), and the increase in primary and secondary oxidation products was determined based on the peroxide and anisidine values, respectively, during the induction period (IP). The results indicated that the evolution of hydroperoxides followed zero-order reaction kinetics during the IP at all temperatures, and their rate of formation was exponentially affected by temperature. It was also deduced that temperature influenced the ratio between primary and secondary oxidation products formation, which decreased as the temperature increased. Additionally, it was possible to predict the oxidation behavior of the soybean biodiesel at room temperature by an exponential model fitted to the IP values at different temperatures $\left(70,80,90,100\right.$, and $\left.110^{\circ} \mathrm{C}\right)$ using the Rancimat apparatus.

KEYWORDS: Oxidation kinetic; Oxidation products; Soybean biodiesel; Temperature; Tocopherols

RESUMEN: Influencia de la temperatura en la oxidación de biodiesel de soja. El propósito de este trabajo es evaluar el efecto de la temperatura en el comportamiento oxidativo del biodiesel. Biodiesel derivado de aceite de soja fue oxidado a diferentes temperaturas (temperatura ambiente, 60 y $110^{\circ} \mathrm{C}$ ) y se evaluaron el contenido de compuestos primarios y secundarios de oxidación mediante el índice de peróxidos y de anisidina, respectivamente, a lo largo del periodo de inducción. Los resultados indicaron que el contenido de hidroperóxidos evolucionó siguiendo una cinética de orden cero a lo largo del periodo de inducción a todas las temperaturas y que su velocidad de formación cambió exponencialmente con la temperatura. También se dedujo que la temperatura influyó en la relación entre la formación de los productos de oxidación primarios y secundarios, disminuyendo a medida que aumentaba la temperatura. Además, fue posible predecir el comportamiento oxidativo del biodiesel de soja a temperatura ambiente ajustando a un modelo exponencial los valores de periodo de inducción obtenidos a diferentes temperaturas $\left(70,80,90,100\right.$ y $\left.110^{\circ} \mathrm{C}\right)$ mediante un equipo Rancimat.

PALABRAS CLAVE: Biodiesel de soja; Cinética de oxidación; Productos de oxidación; Temperatura; Tocoferoles

Citation/Cómo citar este artículo: Pereira GG, Morales A, Marmesat S, Ruiz-Méndez MV, Barrera-Arellano D, Dobarganes MC. 2015. Effect of temperature on the oxidation of soybean biodiesel. Grasas Aceites 66 (2): e072. doi: http://dx.doi.org/10.3989/gya.0835142.

Copyright: (C) 2015 CSIC. This is an open-access article distributed under the terms of the Creative Commons Attribution-Non Commercial (by-nc) Spain 3.0 Licence. 


\section{INTRODUCTION}

Interest in new energy sources, especially for partially replacing fossil fuel, has drawn attention to biodiesel research (Nigam and Sing, 2011). Biodiesel comprises a mixture of alkyl esters obtained by transesterification between a lipid-based feedstock, such as vegetable oils, animal fats, and/or waste cooking oils, and a short-chain alcohol using a catalyst (Giordani et al., 2008). In addition to the status of renewable energy resources, biodiesel presents some advantages compared to fossil fuel, such as its biodegradability, reduced exhaust emissions, higher cetane number, greater lubricity, and safer distribution and storage due to its higher flash point (Hoshino, 2007; Knothe, 2007; Monyem and Van Gerpen, 2001). Furthermore, the production and use of biodiesel has also focused on social inclusion and regional development by generating employment and income, as is the case in Brazil (Suarez, 2006).

An essential feature of a fuel is its ability to resist chemical and physical changes during distribution and storage. Accordingly, biodiesel is more prone to degradation via oxidation than conventional fossilbased fuels due to its content in unsaturated fatty acid chains (Knothe, 2007). Oxidation is a complex autocatalytic reaction that produces a high number of new products. In this context, hydroperoxides, the primary oxidation compounds, are the main compounds formed in the earlier stages of oxidative degradation, which is during the induction period (Jain and Sharma, 2010; Pereira et al., 2013). However, hydroperoxides are quite unstable and easily form secondary oxidation products in the advanced stages of oxidation. These secondary products can originate from rearrangements in monomeric products (keto, hydroxy, and epoxy functional groups), from decomposition into lower-mass products (aldehydes, alcohols and hydrocarbons), or from polymerization (dimers and oligomers) (Frankel, 1984; Knothe, 2007). In this stage of the oxidation process, biodiesel does not fulfill the main quality specifications (Lacoste and Lagardere, 2003) and therefore is not suitable for use. The formation of oxidation compounds negatively affects the mechanical components of engines. For example, hydroperoxides can attack elastomers, acid products formed from hydroperoxide cleavage cause the corrosion of metal systems, and gums and sediments of high-molecular mass can clog injection pumps and filters (Fazal et al., 2010; Monyem and Van Gerpen, 2001; Sorate and Bhale, 2013).

The rates of these oxidation reactions depend on several factors inherent to the biodiesel nature as well as on the external environment and storage conditions. The major constituents of biodiesels are unsaturated fatty acid esters because they are typically produced from vegetable oils, such as soybean and rapeseed (Knothe, 2007; McCormick et al., 2007).
In fact, di- and tri-unsaturated fatty acid chains contain the most reactive sites for hydrogen atom abstraction, making biodiesels with high contents of linolenic and linoleic acids more susceptible to degradation (Knothe and Dunn, 2003). On the other hand, the presence of natural or synthetic antioxidants increases the stability of biodiesel by reducing the rate of free radical propagation (Fröhlich and Schober, 2007). The oxidative degradation of biodiesel occurs primarily as a result of contact with metal, light, air and/or heat during its storage and distribution. Metal and light are pro-oxidants that affect the oxidation rate (Aquino et al., 2012), but contact with air and elevated temperature are the most deleterious parameters related to biodiesel degradation (Godoy et al., 2013). It is recognized that, in general, the rate of a chemical reaction approximately doubles for every $10{ }^{\circ} \mathrm{C}$ increase (Stoker, 2010). For this reason, oxidative stability is even more crucial for biodiesel quality in countries where there are high annual average temperatures, such as Brazil.

It is noteworthy that, in spite of the complex specification of biodiesel, there is no analytical parameter to evaluate their oxidative quality, with the exception of oxidative stability. However, oxidative stability is not a method that measures oxidation status. In this context, in a previous study our research group investigated the evolution of oxidation in soybean oil and its biodiesel under the standard conditions of oxidative stability $\left(110^{\circ} \mathrm{C}\right)$, using a pool of analytical methods. Here, we aimed to expand the research related to biodiesel oxidation, focusing on the effect of temperature on the formation of primary and secondary oxidation products. We further aimed to predict the end of the stability at storage conditions from the results obtained in the accelerated oxidation experiments.

\section{MATERIAL AND METHODS}

\subsection{Biodiesel production}

Soybean oil used in biodiesel production was supplied by Koipe S.A. (Andújar, Jaén, Spain). Transesterification of the oil involved mixing, under constant stirring, $100 \mathrm{~g}$ of soybean oil and $35 \mathrm{~mL}$ of sodium methoxide solution $(1.5 \mathrm{M}$ in methanol) at ambient temperature for 30 minutes. After the reaction, the medium was washed with water to remove impurities, such as glycerol, soaps, catalysts, and methanol residues. The ester fraction was filtered with anhydrous sodium sulfate to eliminate traces of moisture (Tomasevic and Siler-Marinkovic, 2003).

\subsection{Physicochemical characterization of biodiesel}

Fresh soybean biodiesel was characterized by standard methods of oxidation and quality. Fatty acid methyl esters were determined by gas 
chromatography according to the IUPAC method 2.302 (IUPAC, 1992). Mono-, di-, triacylglycerol, and glycerol residues in the fresh soybean biodiesel were determined according to method EN 14105 (CEN, 2003a). The content of nonpolar and polar compounds was determined gravimetrically by IUPAC method 2.507 (IUPAC, 1992) with a slight modification. $150 \mathrm{~mL}$ of hexane/diethyl ether (95:5) were used to elute the nonpolar fraction due to the lower polarity of fatty acid methyl esters compared to that of triacylglycerols. The kinematic viscosity was determined by the method ASTM D7042 (ASTM, 2012). Finally, acid value and oxidative stability were determined following the methods EN 14104 (CEN, 2003b) and EN 14112 (CEN, 2003c), respectively. Oxidative stability is expressed by the induction period, which is the time (in hours) that elapses until the primary and secondary oxidation products increase significantly. This value indicates the resistance of biodiesel to oxidation.

\subsection{Oxidation procedures}

The soybean biodiesel was submitted to three different oxidation procedures, at room temperature, $60{ }^{\circ} \mathrm{C}$, and $110^{\circ} \mathrm{C}$. The conditions for the oxidation procedures were as follows.

\subsubsection{Room temperature}

Samples containing $40 \mathrm{~g}$ of soybean biodiesel were placed in $200 \mathrm{~mL}$ open amber glass containers and kept in the laboratory with exposure to indoor air. Samples were collected for analysis every 10 days, approximately, over a period of 340 days. Average temperatures ranging from 15 to $25^{\circ} \mathrm{C}$ were measured throughout this storage time.

\subsubsection{Oven at $60^{\circ} \mathrm{C}$}

Samples containing $10 \mathrm{~g}$ of soybean biodiesel were placed in Petri dishes with a surface-to-volume ratio of $13 \mathrm{~cm}^{-1}$ and stored in an oven at $60^{\circ} \mathrm{C}$ without exposure to light. Samples were collected for analysis at the following time intervals: $0,2,3,4$, 5,7 , and 8 days.

\subsubsection{Rancimat at $110^{\circ} \mathrm{C}$}

Samples containing $10 \mathrm{~g}$ of soybean biodiesel were placed in Rancimat tubes and then inserted into a Rancimat apparatus (Metrohm, Herisau, Switzerland) with the block temperature set to $110^{\circ} \mathrm{C}$ and with an air flow rate of $20 \mathrm{~L} \cdot \mathrm{h}^{-1}$. Samples were collected for analysis at the following time intervals: $0,1,2,3,4,5$, and $6 \mathrm{~h}$.

In each procedure, samples were collected for analysis at different time intervals until the induction period was exceeded. All the experiments were performed in duplicate.

\subsection{Analysis of biodiesel oxidation}

The oxidation evolution of the soybean biodiesel samples was analyzed by standard methods to determine the primary and secondary oxidation compounds; via the peroxide (AOCS Cd 8b-90) and $p$-anisidine values (AOCS Cd 18-90) (AOCS, 1997). Changes in the tocopherol contents were also monitored by normal high-performance liquid chromatography with fluorescence detection (excitation at $290 \mathrm{~nm}$ and emission at $330 \mathrm{~nm}$ ) according to the IUPAC method 2.432 (IUPAC, 1992). In addition, the useful life of the fresh soybean biodiesel samples was predicted by fitting an exponential equation to the oxidative stability data obtained under the same conditions defined by EN 14112 at different temperatures $\left(70,80,90,100\right.$, and $\left.110^{\circ} \mathrm{C}\right)$.

\subsection{Statistical analysis}

Regression analyses were performed using Excel 2007 software (Microsoft Co., USA).

\section{RESULTS AND DISCUSSION}

The physicochemical characterization data for the fresh soybean biodiesel are given in Table 1. In general, the biodiesel showed good oxidative quality, as verified by the low values of peroxide, anisidine, and polar compounds. In addition, all the parameters, except the acid number and oxidative stability, were in accordance with the European specifications (EN 14214). Although the sample does not meet the specifications for oxidative stability, it is recognized that most of the biodiesels produced from polyunsaturated vegetable oils present low oxidative stability when no antioxidants have been added (Dantas et al., 2011; Jain and Sharma, 2011; Maia et al., 2011). This was also true for the soybean biodiesel used in this study, as evidenced by its major fatty acid methyl esters (C16: 0-10.7\%, C18: 0-3.3\%, C18: 1-21.5\%, C18: $2-51.2 \%$, and C18: $3-5.9 \%$ ). However, the value found for oxidative stability $(5.5 \mathrm{~h})$ met the less rigorous ASTM D 6751 specification (min. $3 \mathrm{~h}$ ).

Figure 1 shows the evolution of hydroperoxides in the soybean biodiesel measured by the peroxide value at the three different temperatures $\left(110^{\circ} \mathrm{C}, 60^{\circ} \mathrm{C}\right.$, and room temperature) as well as the parallel loss of total tocopherols. As can be observed, the peroxide value increased moderately during the induction period (IP); however, a marked increase in the oxidation rate was observed when the IP was exceeded. Interestingly, the sharp increase in the primary oxidation products coincided with the loss of natural tocopherols. It can also be observed that, despite the enormous differences in the IP of the soybean biodiesel samples at different 
• G.G. Pereira, A. Morales, S. Marmesat, M.V. Ruiz-Méndez, D. Barrera-Arellano and M.C. Dobarganes

TABLE 1. Quality and oxidative parameters of soybean biodiesel compared with the EN and ASTM specification limits

\begin{tabular}{|c|c|c|c|}
\hline Physicochemical parameters & ASTM D 6751 limits & EN 14214 limits & Soybean biodiesel \\
\hline Oxidative stability (h) & Min. 3 & Min. 8 & 5.5 \\
\hline Peroxide value (meq $\mathrm{O}_{2} \cdot \mathrm{Kg}^{-1}$ ) & - & - & 5 \\
\hline Acid number $\left(\mathrm{mg} \mathrm{KOH} \cdot \mathrm{g}^{-1}\right)$ & Max. 0.5 & Max. 0.5 & 0.9 \\
\hline Anisidine value & - & - & 0.4 \\
\hline Total tocopherol $\left(\mathrm{mg} \cdot \mathrm{Kg}^{-1}\right)$ & - & - & 785 \\
\hline FAME content $t^{\mathrm{a}}(\%)$ & - & Min. 96.5 & 97.2 \\
\hline Polar compounds (\%) & - & - & 2.8 \\
\hline Kinematic viscosity $\left(\mathrm{mm}^{2} \cdot \mathrm{s}^{-1}\right)$ & $1.9-6.0$ & $3.5-5.0$ & 4.2 \\
\hline Total glycerol (\%) & Max. 0.24 & Max. 0.25 & 0.10 \\
\hline Free glycerol (\%) & Max. 0.02 & Max. 0.02 & 0.02 \\
\hline Monoacylglycerol (\%) & - & Max. 0.8 & 0.22 \\
\hline Diacylglycerol (\%) & - & Max. 0.2 & 0.07 \\
\hline Triacylglycerol (\%) & - & Max. 0.2 & 0.16 \\
\hline
\end{tabular}

${ }^{\mathrm{a}}$ Measured by IUPAC method 2.507 (IUPAC, 1992).
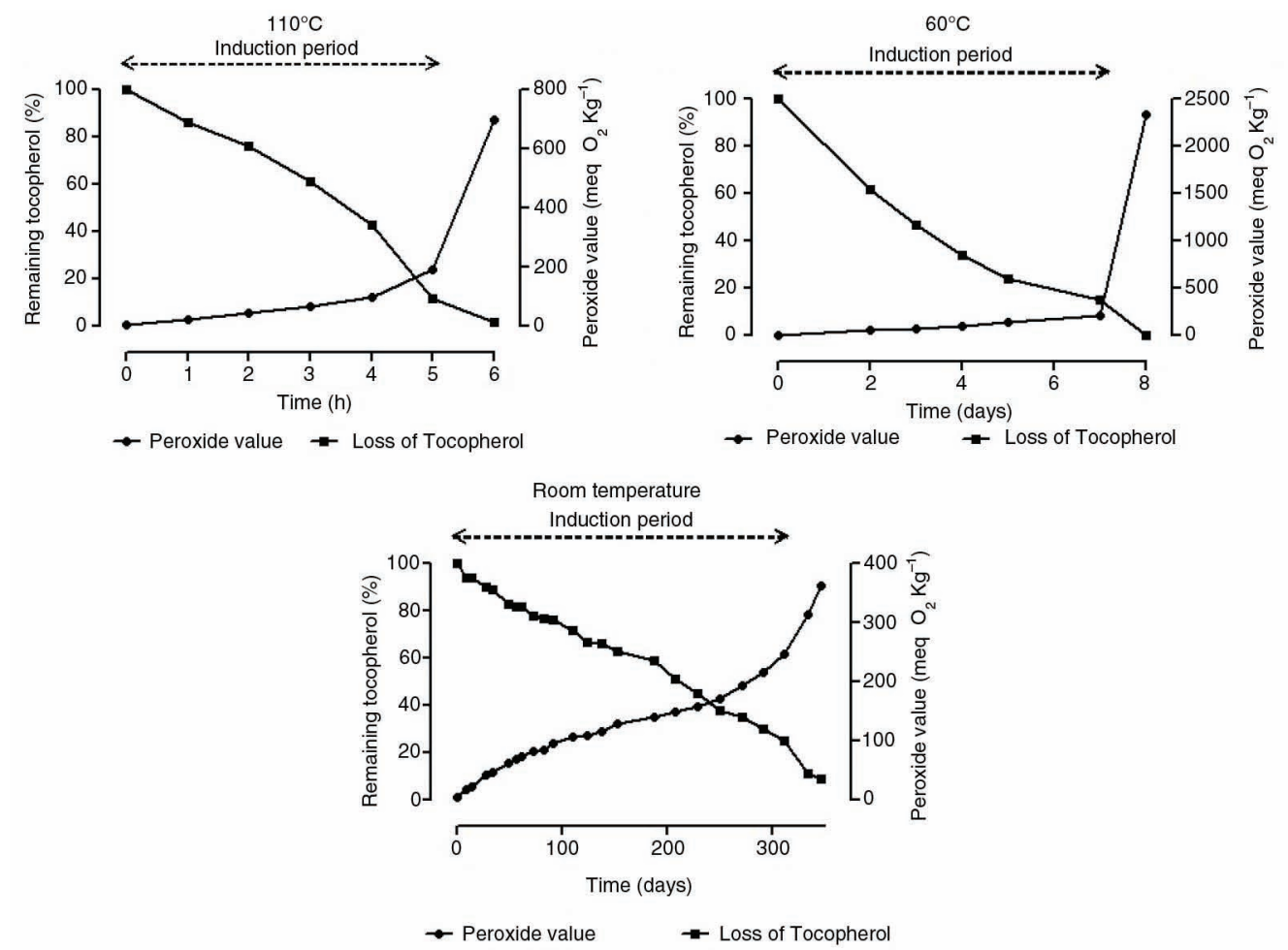

FIGURE 1. Evolution of the peroxide value and remaining tocopherol content in soybean biodiesel at different temperatures*. *Samples were collected for analysis at different time intervals until the induction period was exceeded.

temperatures (5-6 hours, 7-8 days, and approximately 10 months at $110^{\circ} \mathrm{C}, 60^{\circ} \mathrm{C}$, and room temperature, respectively), the levels of natural antioxidants were approximately $15 \%$ for samples close to the end of the IP. Thus, an acceleration in the oxidative degradation of the biodiesel appeared to take place when the level of antioxidants was too low to delay oxidation.

Figure 1 also shows that the peroxide values at the end of the IP decreased as the assay temperature increased. Thus, the last samples before the end of the IP had peroxide values of 191, 212, and 314 meq $\mathrm{O}_{2} \cdot \mathrm{Kg}^{-1}$ at $110^{\circ} \mathrm{C}, 60^{\circ} \mathrm{C}$, and at room temperature, respectively. This may be due to the instability of tocopherols (Márquez-Ruiz et al., 2003) or hydroperoxides at higher temperatures.

The instability of the hydroperoxides was confirmed by determining the anisidine value as a measure of the presence of secondary oxidation 
TABLE 2. Influence of temperature on the formation of primary and secondary oxidation compounds

\begin{tabular}{|c|c|c|c|}
\hline Temperature $\left({ }^{\circ} \mathrm{C}\right)$ & $\begin{array}{l}\text { Peroxide value (PV) } \\
\text { meq } \mathrm{O}_{2} \cdot \mathbf{K g}^{-1}\end{array}$ & $\begin{array}{c}\text { Anisidine } \\
\text { value (AV) }\end{array}$ & PVIAV \\
\hline \multirow[t]{3}{*}{110} & 67 & 7.3 & 9.2 \\
\hline & 99 & 10.1 & 9.8 \\
\hline & 191 & 21.2 & 9.0 \\
\hline \multirow[t]{4}{*}{60} & 76 & 3.1 & 24.8 \\
\hline & 104 & 4.1 & 25.4 \\
\hline & 140 & 5.7 & 24.6 \\
\hline & 212 & 9.0 & 23.6 \\
\hline
\end{tabular}

compounds, specifically aldehydes. Table 2 shows the peroxide and anisidine values as well as the ratio between the two indices for selected samples before the end of the IP at $110^{\circ} \mathrm{C}$ and $60^{\circ} \mathrm{C}$. It can be clearly observed that the formation of secondary oxidation compounds, as determined by the increases in the anisidine value, was much higher at $110^{\circ} \mathrm{C}$ than at $60{ }^{\circ} \mathrm{C}$ for similar levels of hydroperoxides. This fact can be explained by the decomposition of the hydroperoxides, which occurred in a fast rate at $110^{\circ} \mathrm{C}$. Additionally, it is interesting to observe that the ratios between the indices were similar throughout the IP at each temperature, i.e. around 9 and 24 at 110 and $60{ }^{\circ} \mathrm{C}$, respectively.

Figure 1 also shows that hydroperoxide formation appears to follows zero-order reaction kinetics during the IP. This behavior was confirmed in Figure 2, where the peroxide values were fit to a linear model with high coefficients of correlation $(r>0.98)$. The linear model follows equation 1:

$\mathrm{PV}=\mathrm{k} \cdot \mathrm{t}+\mathrm{b}$

where $\mathrm{PV}=$ peroxide value (meq $\mathrm{O}_{2} \mathrm{Kg}^{-1}$ ), $\mathrm{k}=$ the rate of hydroperoxide formation (meq $\mathrm{O}_{2} \cdot \mathrm{Kg}^{-1} \mathrm{~h}^{-1}$ ), $\mathrm{t}=$ the time of oxidation (h), and $b=$ the intercept of the PV-axis. It is interesting to note that the poorer fit of the equation to the room conditions was due to the variable temperature $\left(15-25^{\circ} \mathrm{C}\right)$, with the high initial slope corresponding to the summer season (approximately $25^{\circ} \mathrm{C}$ ). From the slopes of the equations (k), it was possible to obtain the rates of hydroperoxide formation, which were calculated to be 23.1, 1.23, and 0.027 meq $\mathrm{O}_{2} \cdot \mathrm{Kg}^{-1} \mathrm{~h}^{-1}$ at $110^{\circ} \mathrm{C}, 60^{\circ} \mathrm{C}$, and ambient conditions, respectively (Figure 2). Therefore, increasing the temperature to $60^{\circ} \mathrm{C}$ and $110^{\circ} \mathrm{C}$ accelerated the oxidation rate 45 - and 855 -fold, respectively, relative to the ambient conditions. These results indicate that temperature has an exponential influence on the oxidation rate of the soybean biodiesel. Accordingly, the storage and distribution temperatures of biodiesel are critical variables that determine its quality and useful life.

We further aimed to determine whether the end of the IP at storage conditions could be deduced from the results obtained from the accelerated oxidation experiments. For this purpose, we determined the IP using a Rancimat apparatus under the same conditions defined by EN 14112 at different temperatures $\left(70-110^{\circ} \mathrm{C}\right)$. Figure 3 shows that the IP and temperature followed an exponential
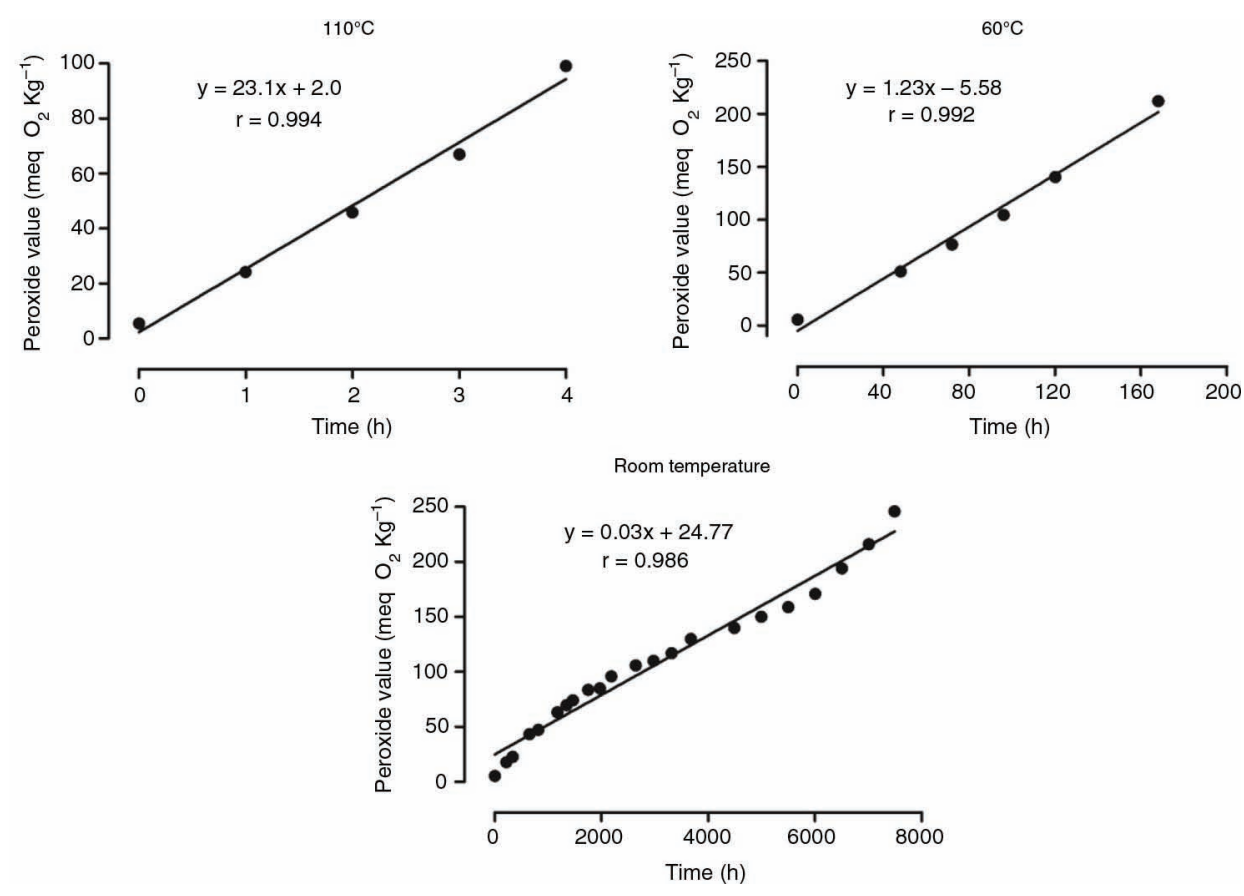

FIGURE 2. Kinetics of hydroperoxide formation in soybean biodiesel samples oxidized at different temperatures*. *Samples were collected for analysis at different time intervals until the induction period. 


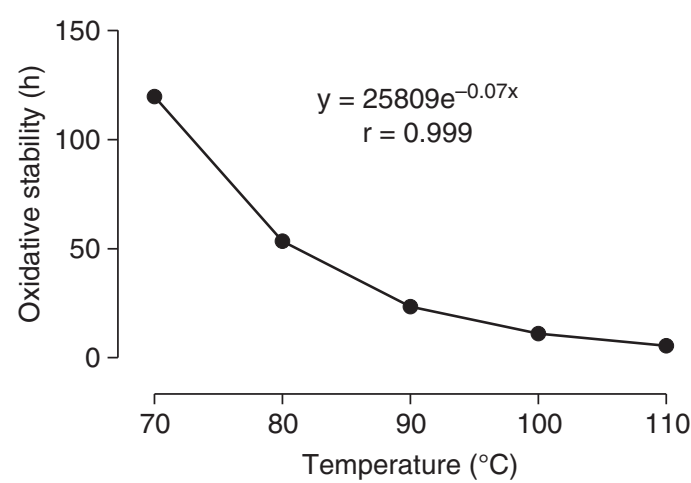

FIGURE 3. Exponential relationship between the induction period (IP) and the temperature obtained by a Rancimat apparatus* *Oxidative stability data at different temperatures: $70^{\circ} \mathrm{C}=120 \mathrm{~h}$, $80{ }^{\circ} \mathrm{C}=53 \mathrm{~h}, 90^{\circ} \mathrm{C}=23 \mathrm{~h}, 100^{\circ} \mathrm{C}=11 \mathrm{~h}$, and $110^{\circ} \mathrm{C}=5.5 \mathrm{~h}$.

model with an excellent coefficient of correlation $(r=0.999)$. The end of the IP, as extrapolated by the exponential model at room temperature $\left(15-25^{\circ} \mathrm{C}\right)$, occurred between 186 and 376 days. From the experimental data, this event occurred at approximately 314 days, as can be observed by the sharp increase in the peroxide value (Figure 1). Consequently, it is noteworthy that the end of the IP under ambient conditions could be predicted by an exponential model similar to that proposed in Figure 3. Although the end of IP depends on the different variables of the biodiesel sample and storage conditions, its determination by accelerated condition tests may be a practical tool in the routine analysis of biodiesel.

\section{CONCLUSIONS}

In conclusion, the results obtained in this paper indicate that the oxidation behavior of soybean biodiesel followed a general pattern. Temperature negatively affected the biodiesel quality, reducing its oxidative stability and consequently accelerating the formation of oxidation products. In this context, elevated temperatures increased the rate of hydroperoxide formation and also favored the emergence of secondary products, which are harmful to engine and fuel systems. Finally, we verified the usefulness of an exponential model fit to the IP values at different temperatures to predict the end of the induction period of a biodiesel during storage.

\section{ACKNOWLEDGMENTS}

The authors are grateful to the São Paulo Research Foundation (FAPESP) for their financial support and to the Coordination for the Improvement of Higher Level or Education Personnel (CAPES) for a scholarship (Process $n^{\circ}$ BEX 6667/12-0).

\section{REFERENCES}

AOCS. 1997. American Oil Chemists' Society. Official methods and recommended practices of the AOCS. AOCS, Champaign.

ASTM. 2012. American Society for Testing and Materials. Method ASTM D7042 - Standard test method for dynamic viscosity and density of liquids by Stabinger viscosimeter (and calculation of kinematic viscosity). ASTM, West Conshohocken.

Aquino IP, Hernandez RPB, Chicoma DL, Pinto HPF, Aoki IV. 2012. Influence of light, temperature and metallic ions on biodiesel degradation and corrosiveness to copper and brass. Fuel 102, 795-807. http://dx.doi.org/10.1016/j. fuel.2012.06.011.

Dantas MB, Albuquerque AR, Barros AK, Rodrigues Filho MG, Antoniosi Filho NR, Sinfrônio FSM, Rosenhaim R, Soledade LEB, Santos IMG, Souza AG. 2011. Evaluation of the oxidative stability of corn biodiesel. Fuel 90, 773778. http://dx.doi.org/10.1016/j.fuel.2010.09.014.

CEN. 2003a. European Committee for Standardization. Method EN 14105 - Determination of free and total glycerol and mono-, di-, triglyceride contents. CEN, Brussels.

CEN. 2003b. European Committee for Standardization. Method EN 14104 - Determination of acid value. CEN, Brussels.

CEN. 2003c. European Committee for Standardization. Method EN 14112 - Determination of oxidation stability. CEN, Brussels.

Fazal MA, Haseeb ASMA, Masjuki HH. 2010. Comparative corrosive characteristics of petroleum diesel and palm biodiesel for automotive materials. Fuel Process. Technol. 91, 1308-1315. http://dx.doi.org/10.1016/j.fuproc.2010.04.016.

Frankel EN. 1984. Lipid oxidation: mechanisms, products and biological significance. J. Am. Oil Chem. Soc. 61, 1908-1917. http://dx.doi.org/10.1007/BF02540830.

Fröhlich A, Schober S. 2007. The influence of tocopherols on the oxidation stability of methyl esters. J. Am. Oil Chem. Soc. 84, 579-585. http://dx.doi.org/10.1007/s11746-007-1075-z.

Giordani DS, Siqueira AF, Silva MLCP, Oliveira PC, Castro HF. 2008. Identification of the biodiesel source using an electronic nose. Energy Fuels 22, 2743-2747. http://dx.doi. org/10.1021/ef700760b.

Godoy AT, Pereira GG, Ferreira LL, Cunha IBS, BarreraArellano D, Daroda RJ, Eberlin MN, Alberici RM. 2013. Biodiesel oxidation monitored by ambient desorption/ ionization mass spectrometry. Energy Fuels 27, 7455-7459. http://dx.doi.org/10.1021/ef4015422.

Hoshino T, Iwata Y, Koseki H. 2007. Oxidation stability and risk evaluation of biodiesel. Therm. Sci. 11, 87-100. http:// dx.doi.org/10.2298/TSCI0702087H.

IUPAC. 1992. International Union of Pure and Applied Chemistry. Standard Methods for the Analysis of Oils, Fats and Derivates. 7. ed. International Union of Pure Applied Chemistry, Blackwell Scientific, Oxford.

Jain S, Sharma MP. 2010. Stability of biodiesel and its blends: a review. Renew. Sustain. Energy Rev. 14, 667-678. http:// dx.doi.org/10.1016/j.fuel.2011.05.003.

Jain S, Sharma MP. 2011. Oxidation stability of blends of jatropha biodiesel with diesel. Fuel 90, 3014-3020.

Knothe G, Dunn RO. 2003. Dependence of oil stability index of fatty compounds on their structure and concentration and presence of metals. J. Am. Oil Chem. Soc. 80, 1021-1026. http://dx.doi.org/10.1007/s11746-003-0814-x.

Knothe G. 2007. Some aspects of biodiesel oxidative stability. Fuel Process. Technol. 88, 669-677. http://dx.doi.org/10.1016/ j.fuproc.2007.01.005

Lacoste F, Lagardere L. 2003. Quality parameters evolution during biodiesel oxidation using rancimat test. Eur. J. Lipid. Sci. Technol. 105, 149-155. http://dx.doi.org/10.1002/ejlt. 200390030.

Maia ECR, Borsato D, Moreira I, Spacino KR, Rodrigues PRP, Gallina AL. 2011. Study of the biodiesel B100 oxidative stability in mixture with antioxidants. Fuel Process. Technol.92, 1750-1755. http://dx.doi.org/10.1016/j.fuproc.2011.04.028. 
Márquez-Ruiz G, Martín-Polvillo M, Dobarganes C. 2003. Effect of temperature and addition of alpha-tocopherol on the oxidation of trilinolein model systems. Lipids $\mathbf{3 8}$, 233-40. http://dx.doi.org/10.1007/s11745-003-1056-2.

McCormick RL, Ratcliff M, Moens L, Lawrence R. 2007. Several factors affecting the stability of biodiesel in standard accelerated tests. Fuel Process. Technol. 88, 651-657. http://dx.doi.org/10.1016/j.fuproc.2007.01.006

Monyem A, Van Gerpen JH. 2001. The effect of biodiesel oxidation on engine performance and emissions. Biomass Bioenergy 20, 317-325. http://dx.doi.org/10.1016/S09619534(00)00095-7.

Nigam PS, Singh A. 2011. Production of liquid biofuels from renewable resources. Prog. Energy Combust. Sci. 37, 52-68. http://dx.doi.org/10.1016/j.pecs.2010.01.003.
Pereira GG, Marmesat S, Barrera-Arellano D, Dobarganes MC. 2013. Evolution of oxidation in soybean oil and its biodiesel under the conditions of the oxidation stability test. Grasas Aceites 64, 482-488. http://dx.doi.org/10.3989/ gya.036913.

Sorate KA, Bhale PV. 2013. Impact of biodiesel on fuel system materials durability. J. Sci. Ind. Res. 72, 48-57.

Stoker HS. 2010. General, organic, and biological chemistry. Cengage Learning, Belmont.

Suarez PAZ. 2006. O biodiesel e a política de C \& T brasileira. Quim. Nova 29, 1157-1157. http://dx.doi.org/10.1590/S010040422006000600001 .

Tomasevic AV, Siler-Marinkovic SS. 2003. Methanolysis of used frying oil. Fuel Process. Technol. 81, 1-6. http://dx.doi. org/10.1016/S0378-3820(02)00096-6. 